\title{
Bone Marrow-Derived Lymphoid Cell Lines from Patients with Agammaglobulinemia
}

\author{
Jerrold Schwaber, Herbert lazarus, and Fred S. Rosen, The Division \\ of Immunology, Children's Hospital Medical Center, the Sidney Farber Cancer \\ Institute, and the Departments of Pediatrics and Pathology, Harvard Medical \\ School, Boston, Massachusetts 02115
}

\begin{abstract}
A B S T RACT In vitro infection with Epstein-Barr virus of bone marrow-derived (B) lymphocytes from blood of patients with X-linked or common varied agammaglobulinemia resulted in the establishment of long-term B-lymphoid cell lines (LCL). LCL were established only with B lymphocytes from patients whose B cells failed to respond to in vitro mitogenic stimulation. In contrast, lymphocytes from patients without small B lymphocytes or with B cells that synthesized but failed to secrete Ig failed uniformly to establish LCL. Analysis of the "nonsecretory" B lymphocytes demonstrated the presence of receptors for C3b and C3d as well as surface Ig, but absence of detectable receptors for Epstein-Barr virus.

All of the six cell lines that were established formed rosettes with EAC3 but not with sheep erythrocytes. Four of the six LCL were principally surface IgD bearing and did not synthesize detectable Ig for secretion. Two of the cell lines were indistinguishable from cell lines from normal individuals: they had surface IgG, $\mathrm{A}, \mathrm{M}$, and $\mathrm{D}$ and synthesized and secreted Ig.
\end{abstract}

\section{INTRODUCTION}

Agammaglobulinemia is a heterogeneous immunodeficiency disease resulting from the failure of development or differentiation of bone marrow-derived (B) lymphocytes. ${ }^{1}$ Most, but not all, patients with the $\mathrm{X}$-linked form of agammaglobulinemia lack small B lymphocytes, as defined by surface Ig, C3 receptors, and Epstein-Barr virus (EBV) receptors (1-3). Some

Received for publication 31 October 1977 and in revised form 5 April 1978 .

${ }^{1}$ Abbreviations used in this paper: B, bone marrow-derived; BSA, bovine serum albumin; E, sheep erythrocytes; EBSS, Earle's balanced salt solution; EBV, Epstein-Barr virus; FBS, fetal bovine serum; LCL, lymphoid cell line; LMF, lymphocyte mitogenic factor; PWM, pokeweed mitogen; SDS, sodium dodecyl sulfate; TCA, trichloroacetic acid. experiments have suggested that these patients have precursor cells that may be induced to differentiate under appropriate circumstances $(4,5)$. In contrast, patients diagnosed to have the common variable form of agammaglobulinemia usually have normal numbers of small B lymphocytes (6-10). Their B cells fail to produce imunoglobulin in response to mitogenic stimulation. Lymphocytes from a few patients have been reported to respond to mitogenic stimulation by the production of intracellular immunoglobulin that was not secreted $(6,8,10)$.

In vitro stimulation of peripheral lymphocytes by mitogens, including pokeweed mitogen (PWM), lymphocyte mitogenic factor (LMF), or EBV, results in the increased synthesis and eventual secretion of IgM or IgG by B lymphocytes (11-15). Morphologically, the small B lymphocytes enlarge and undergo mitosis, and differentiate into immunoglobulin-secreting lymphoblasts. In cultures stimulated by PWM and LMF, some of these lymphoblasts mature into plasma cells (15). In cultures stimulated by EBV, some of the lymphoblasts are immortalized, giving rise to long-term lymphoid cell lines that secrete immunoglobulin, usually of several classes (16-18). These cells have surface receptors for $\mathrm{C} 3, \mathrm{Fc}$, and $\mathrm{EBV}$ and bear surface immunoglobulin, usually of several heavy chain classes.

We attempted to establish long-term lymphoid cell lines from agammaglobulinemic patients by in vitro transformation of lymphocytes with EBV. The ability of lymphocytes from patients with agammaglobulinemia to give rise to established cell lines would serve to characterize B-cell developmental stages present in the peripheral blood. Characterization of the immunologic properties of the cell lines would permit determination of B cell-associated defects including failure of immunoglobulin production. Finally, cell lines derived from agammaglobulinemic patients that failed to produce immunoglobulin might serve to define stages in B-cell development and differentiation. 


\section{METHODS}

Patients. Lymphocytes from 14 patients with a primary diagnosis of agammaglobulinemia were used in experiments to start lymphoid cell lines (Table I). Four patients were diagnosed to have the $\mathrm{X}$-linked form of agammaglobulinemia. Before treatment, they had serum IgG $<50 \mathrm{mg} / 100 \mathrm{ml}$; IgM and IgA were undetectable. Onset of the disease in these patients was before $2 \mathrm{yr}$ of age. Each patient had a maternal male relative with agammaglobulinemia. 10 patients were diagnosed to have the common variable form of agammaglobulinemia. Before treatment, IgG was $<200 \mathrm{mg} / 100 \mathrm{ml}$, IgM $<50 \mathrm{mg} / 100 \mathrm{ml}$, and IgA $<50 \mathrm{mg} / 100 \mathrm{ml}$. Onset of the disease ranged from before $2 \mathrm{yr}$ of age to $50 \mathrm{yr}$ of age. Two patients were brothers.

Lymphocytes from most of these 13 patients had been previously characterized by EAC3 rosette formation and surface immunofluorescence $(3,8)$. Additionally, lymphocytes were fractionated on discontinuous gradients of bovine serum albumin (BSA), yielding "precursor" cell, T cell-, and B cellrich fractions. B-lymphocyte fractions from patients with B cells had been tested for synthesis and secretion of Ig in vitro in response to a $\mathrm{T}$ cell-derived mitogen (LMF).

All patients except patient 1.14 were without other disease at the time of study. Patient 1.14 had a benign lymphoproliferative disorder. Peripheral blood was the source of lymphocytes from all patients except patient 1.14 from whom spleen cells were obtained at splenectomy. All patients were on gamma globulin replacement therapy. All procedures were approved by the Committee on Clinical Investigation and informed consent was obtained.

Lymphocyte cell cultures. Peripheral blood was collected in preservative-free heparin (Sigma Chemical Co., St. Louis,

TABLE I

Patients Studied

\begin{tabular}{|c|c|c|c|c|c|}
\hline \multirow[b]{2}{*}{ Patient } & \multirow[b]{2}{*}{ Age } & \multicolumn{2}{|c|}{ Peripheral blood } & \multirow[b]{2}{*}{ Response to LMF } & \multirow[b]{2}{*}{$\begin{array}{l}\text { Designation } \\
\text { of LCL }\end{array}$} \\
\hline & & B cells & $\begin{array}{l}\text { Diag- } \\
\text { nosis }\end{array}$ & & \\
\hline & $y r$ & & & & \\
\hline 8.20 & 22 & - & XLA* & - & \\
\hline 10.10 & 19 & - & XLA & - & \\
\hline 20.16 & 14 & - & XLA & - & \\
\hline 4.8 & 13 & + & XLA & No Ig synthesis & LAZ 166 \\
\hline $1.3 \ddagger$ & 26 & - & CVA§ & - & \\
\hline $23.3 \ddagger$ & 23 & - & CVA & - & \\
\hline 5.6 & 19 & + & CVA & No Ig synthesis & LAZ 135 \\
\hline 4.23 & 31 & + & CVA & No Ig synthesis & $\begin{array}{l}\text { LAZ 153, } \\
\quad \mathrm{S}-2\end{array}$ \\
\hline 10.13 & 25 & + & CVA & $\begin{array}{l}\text { Ig synthesis, } \\
\text { No secretion }\end{array}$ & \\
\hline 18.12 & 14 & + & CVA & $\begin{array}{l}\text { Ig synthesis, } \\
\text { No secretion }\end{array}$ & \\
\hline 20.3 & 15 & + & CVA & $\begin{array}{l}\text { Ig synthesis, } \\
\text { No secretion }\end{array}$ & \\
\hline 1.14 & 55 & + & CVA & Not tested & LAZ 165 \\
\hline 18.3 & 8 & + & CVA & No Ig synthesis & LAZ 184 \\
\hline 10.2 & 16 & + & CVA & No Ig synthesis & LAZ 202 \\
\hline
\end{tabular}

* X-linked agammaglobulinemia.

‡ Siblings.

$\S$ Common varied form of agammaglobulinemia.
Mo.), and lymphocytes were separated by Ficoll-Hypaque (Pharmacia Fine Chemicals, Piscataway, N. J.) sedimentation (19). Primary cultures were seeded at $d 2 \times 10^{6}$ cells $/ \mathrm{ml}$ in $10-\mathrm{ml}$ cultures and were fed twice a week by allowing the cells to sediment at unit gravity for $1 \mathrm{~h}$ at $37^{\circ} \mathrm{C}$ followed by removal of $3 \mathrm{ml}$ of the supernate and replacement with $3 \mathrm{ml}$ of fresh media. Primary cultures were initiated and maintained in medium composed of $100 \mathrm{ml}$ RPMI 1629 (20), $20 \mathrm{ml}$ fetal bovine serum (FBS), $1 \mathrm{ml}$ horse serum, $1 \mathrm{ml}$ of $100 \mathrm{mM}$ sodium pyruvate, $1 \mathrm{ml}$ of $100 \times$ Eagle's "nonessential" amino acids (21), $1 \mathrm{ml}$ of $\mathrm{mM} 2$-mercaptoethanol (22) and $1 \mathrm{ml}$ of $1 \times 10^{4} \mathrm{U} / \mathrm{ml}$ sodium penicillin $\mathrm{G}, 1 \times 10^{4} \mu \mathrm{g} / \mathrm{ml}$ streptomycin sulfate, and $0.2 \mathrm{M}$ L-glutamine.

Transforming virus was obtained from the marmoset lymphoblastoid cell line, B95-8 $(23,24)$ (starter culture was provided by Dr. George Miller, Yale University School of Medicine). One-tenth $\mathrm{ml}$ of virus-containing medium was added per milliliter of culture. All cultures were maintained for a minimum of $8 \mathrm{wk}$ or until there were no viable cells left in the culture. Proliferation of viral-transformed cells usually occurred within 4-6 wk. The cultures were expanded by the addition of fresh medium until there were adequate numbers of cells to be stored in liquid nitrogen. Cells to be frozen were washed and resuspended in culture medium with $7.5-10 \%$ dimethyl sulfoxide (DMSO) at $d 3 \times 10^{7}$ cells $/ \mathrm{ml}$. At the time of freezing and periodically thereafter, all cell lines were tested for Mycoplasma contamination and found to be negative by growth on Mycoplasma test plates (Grand Island Biological Co., Grand Island, N. Y.).

Cell culture and cell lines. After a cell line was established, it was grown in RPMI 1640 medium (25) or Eagle's suspension minimal essential medium (22) supplemented with $10 \% \mathrm{FBS}, 1 \mathrm{ml}$ of $1 \times 10^{4} \mathrm{U} / \mathrm{ml}$ sodium penicillin $\mathrm{G}$, $1 \times 10^{4} \mu \mathrm{g} / \mathrm{ml}$ streptomycin sulfate, and $0.2 \mathrm{M}$ L-glutamine, $1 \mathrm{ml}$ Eagle's nonessential amino acids, and $1 \mathrm{ml}$ of $1 \mathrm{mM}$ sodium pyruvate $/ 100 \mathrm{ml}$ medium.

Three long-term lymphoid cell lines were used for normal controls. CCRF CEM is a T-cell line derived from a patient with acute lymphoblastic leukemia $(26,27)$. LAZ 67 and RPMI 1788 are B-cell lines derived from normal donors.

Mononuclear peripheral blood lymphocytes were isolated from heparinized blood by density centrifugation over FicollHypaque gradients (19). In some experiments, cells were fractionated into "precursor," T cell-, and B cell-rich fractions on discontinuous gradients of BSA (28). The gradients were constructed in $2 \%$ decrements, starting with $35 \%$ as the bottom layer, and decreasing to $17 \%$ albumin (layer 1 ). Layers 1, 2, and 3 were pooled to form the precursor-cell fraction (17), layers 4 and 5 were pooled to constitute the $T$ cell-rich fraction 2 , and layers 6,7 , and 8 were pooled to form the $\mathrm{B}$ cell-rich fraction 3. Monocyte contamination was almost completely confined to fraction 1 .

Rosette formation. For rosette formation, cells were suspended at $2 \times 10^{6}$ cells $/ \mathrm{ml}$ in Earle's balanced salt solution (EBSS) with $2 \%$ FBS which had been absorbed with sheep erythrocytes (E). For $\mathrm{E}$ rosettes, $0.05 \mathrm{ml}$ of a $10 \%$ suspension of $\mathrm{E}$ was added to $1 \mathrm{ml}$ of cell suspension, incubated at $37^{\circ} \mathrm{C}$ for $30 \mathrm{~min}$, centrifuged at $200 \mathrm{~g}$ for $5 \mathrm{~min}$, and then incubated at $4^{\circ} \mathrm{C}$ for $2 \mathrm{~h}$. E coated with antibody and the first four components of complement (EAC3b) were prepared. EAC3d (mouse) was prepared with the substitution of fresh mouse serum for the human complement components. The purity of EAC3d reagent was verified by its failure to form rosettes with human erythrocytes, demonstrating the absence of EAC3b (29-31).

One-tenth $\mathrm{ml}$ of $1 \%$ EAC3 was added to $0.1 \mathrm{ml}$ of cell suspension, the mixture was centrifuged at $200 \mathrm{~g}$ for $5 \mathrm{~min}$, and incubated at $37^{\circ} \mathrm{C}$ for $90 \mathrm{~min}$. The percent $\mathrm{E}$ and EAC3 rosette 
formation was determined by counting at least 200 cells in a hemocytometer.

Antisera. Rabbit antisera to human heavy and light chains were purchased from Behring Diagnostics (Somerville, N. J.). They were rendered specific by absorption with appropriate myeloma proteins coupled to Sepharose (Pharmacia Fine Chemicals) (32). For fluorescent antibody procedures, the IgG fraction of each antisera was separated by chromatography on DEAE-cellulose (0.015 M phosphate buffer, $\mathrm{pH} 6.8)$. They were conjugated to fluorescein isothiocyanate (BioQuest, BBL \& Falcon Products, Div. of Becton, Dickinson \& Co., Cockeysville, Md.) as previously described (33). Before use, fluorescent antisera were centrifuged at $100,000 \mathrm{~g}$ for $1 \mathrm{~h}$ to remove aggregated material. For immune precipitation, monospecific antiserum to rabbit IgG was raised in a goat.

Fluorescent antibody. Living cells $\left(1 \times 10^{6},>90 \%\right.$ viable by trypan blue dye exclusion) were washed three times with EBSS and resuspended in $50 \mu \mathrm{l}$ of appropriately diluted test antiserum. They were incubated for $40 \mathrm{~min}$ at $4^{\circ} \mathrm{C}$, washed three times with cold EBSS, resuspended in $50 \%$ glycerol: $50 \%$ EBSS, and dropped on microscope slides. Fixed cells were prepared with a Shandon-Elliot cytocentrifuge (Shandon Southern Instruments Inc., Sewickley, Pa.). Slides were fixed with $5 \%$ (vol/vol) acetic acid in $96 \%$ ethanol at $-20^{\circ} \mathrm{C}$ for $30 \mathrm{~min}$ (34). Slides were stained with the appropriate antisera for $40 \mathrm{~min}$ in a humid chamber, washed with three changes of EBSS, and mounted in 50\% glycerol:50\% EBSS. Cells were examined with a Zeiss fluorescence microscope (Carl Zeiss, Inc., New York) equipped with an HBO $200 \mathrm{~W}$ mercury lamp, a BG 12 primary filter, and a K 510 secondary filter.

EBV receptors were determined as described by Jondal et al. (35). Virus from the B95-8 cell line $(23,24)$ was incubated with the cells for $60 \mathrm{~min}$ with shaking at $4^{\circ} \mathrm{C}$. The cells were washed three times with cold EBSS, and then incubated with $50 \mu \mathrm{l}$ of fluorescein isothiocyanate-conjugated human reference anti-EBV MA serum (Mutua, kindly provided by Dr. M. Jondal), for $30 \mathrm{~min}$. Cells were then washed three times with cold EBSS and examined immediately with a fluorescence microscope.

Immunoglobulin synthesis and secretion. Cells were washed twice with EBSS and resuspended at $5 \times 10^{6}$ cells $/ \mathrm{ml}$ in Eagle's minimal essential medium without leucine supplemented with $10 \%$ dialyzed FBS, $1 \mathrm{ml}$ of $200 \mathrm{mM}$ L-glutamine $/ 100 \mathrm{ml}$ medium, and $2 \mu \mathrm{Ci}\left[{ }^{14} \mathrm{C}\right]$ leucine/ml (New England Nuclear, Boston, Mass.). The cells were incubated for $12-14 \mathrm{~h}$, after which the supernatant medium was collected, the cells washed twice with EBSS, and lysed by the addition of Nonidet P-40 (Bethesda Research Laboratories, Rockville, Md.) to $0.6 \%$. After $30 \mathrm{~min}$, the cell lysate was centrifuged at $2,000 \mathrm{~g}$ for $20 \mathrm{~min}$ to remove cell debris.

Aliquots of the cell supernatant medium and the cell lysate were examined for Ig by the addition of specific antiserum, followed $1 \mathrm{~h}$ later by the addition of goat antiserum to rabbit IgG at equivalence. Controls included precipitation with normal rabbit serum and specific precipitation of solutions in which normal rabbit serum had been precipitated. The mixtures were incubated at $4^{\circ} \mathrm{C}$ overnight, washed three times with cold EBSS, and resuspended in $2 \%$ sodium dodecyl sulfate (SDS), 1\% 2-mercaptoethanol. The reduced proteins were alkylated with iodoacetic acid.

Immune precipitates were electrophoresed in $7.5 \%$ acrylamide slab gels with SDS-phosphate buffer (36). The slab gels were dried in a Hoefer gel drying apparatus (Hoefer Scientific Instruments, San Francisco, Calif.) and autoradiographed with Kodak RPR 54 X-ray film (Eastman Kodak Co., Rochester, N. Y.) to detect de novo immunoglobulin synthesis and secretion.
Immunoglobulin production by the cell lines was also assessed by comparison of the radioactive material precipitable with antiserum to Ig with trichloroacetic acid(TCA)-precipitable material. 40,000,000 cells were incubated in RPMI 1640 medium with $1 / 2$ normal concentration of cold leucine with $2 \mu \mathrm{Ci}\left[{ }^{14} \mathrm{C}\right] l$ leucine/ml for $18-20 \mathrm{~h}$. Medium or cells were coprecipitated in triplicate with $(a)$ normal rabbit serumgoat antiserum to rabbit IgG, $(b)$ rabbit antiserum to human Ig (heavy and light chain specific)-goat antiserum to rabbit IgG, and (c) $10 \%$ TCA. All precipitates were redissolved in $0.5 \mathrm{~N} \mathrm{NaOH}$, neutralized, and assayed in a Packard Scintillation Counter (Packard Instrument Co., Inc., Downers Grove, Ill.) with Insta-Gel.

\section{RESULTS}

Establishing lymphoid cell lines. Concurrent studies indicated that long-term lymphoid cell lines (LCL) could be readily established from normal individuals by EBV obtained from the B95-8 cell line. From 300 attempts to establish LCL from normal and control peripheral blood samples $95 \%$ success was achieved.

Peripheral lymphocytes were isolated from venous blood of immunodeficient patients by density centrifugation over Ficoll-Hypaque. Table II shows the results of attempts to initiate LCL with and without EBV.

Five patients with $\mathrm{X}$-linked or common varied agammaglobulinemia, whose peripheral blood lacked B lymphocytes as defined by EAC3 rosette formation and surface Ig were studied (patients 8.20, 10.10, 20.16, 1.3, and 23.3). 15 cultures were initiated from these patients, all of which failed to yield long-term LCL. 11 of these were from 3 patients with X-linked agammaglobulinemia without $\mathrm{B}$ lymphocytes. The remaining

TABLE II

Establishing Lymphoid Cell Lines

\begin{tabular}{|c|c|c|c|c|c|c|}
\hline \multirow[b]{2}{*}{ Patient } & \multirow[b]{2}{*}{ B cell } & \multicolumn{2}{|c|}{$\begin{array}{l}\text { Cultures } \\
\text { initiated }\end{array}$} & \multicolumn{2}{|c|}{$\begin{array}{l}\text { Cultures } \\
\text { established }\end{array}$} & \multirow[b]{2}{*}{ Cell line } \\
\hline & & $\begin{array}{l}\text { With } \\
\text { EBV }\end{array}$ & $\begin{array}{c}\text { Without } \\
\text { EBV }\end{array}$ & $\begin{array}{l}\text { With } \\
\text { EBV }\end{array}$ & $\begin{array}{l}\text { Without } \\
\text { EBV }\end{array}$ & \\
\hline 8.20 & - & 2 & 2 & 0 & 0 & \\
\hline 10.10 & - & 3 & 0 & 0 & - & \\
\hline 20.16 & - & 6 & 2 & 0 & 0 & \\
\hline 4.8 & + & 2 & 2 & 2 & 0 & LAZ 166 \\
\hline 1.3 & - & 2 & 0 & 0 & - & \\
\hline 23.3 & - & 2 & 0 & 0 & - & \\
\hline 5.6 & + & 5 & 2 & 5 & 0 & LAZ 135 \\
\hline 4.23 & + & 6 & 0 & 6 & - & LAZ 153, S-2 \\
\hline 10.13 & + & 6 & 0 & 0 & - & \\
\hline 18.12 & + & 4 & 2 & 0 & - & \\
\hline 20.3 & + & 6 & 0 & 0 & - & \\
\hline 1.14 & + & 2 & 2 & $2^{*}$ & 0 & LAZ 165 \\
\hline 18.3 & + & 2 & 2 & 2 & 0 & LAZ 184 \\
\hline 10.2 & + & 2 & 2 & 2 & 0 & LAZ 202 \\
\hline
\end{tabular}

* These cultures finally were established 6 mo after incubation. 
four were from two patients with the common varied form of agammaglobulinemia whose blood also lacked B lymphocytes.

Four patients with common varied agammaglobulinemia had B lymphocytes that failed to synthesize Ig in short-term culture in response to $\mathrm{T}$ cell-derived LMF (patients 5.6, 4.23, 10.2, and 18.3). 15 cultures of lymphocytes from these patients were initiated with EBV. All 15 of these cultures resulted in the establishment of LCL.

Splenic lymphocytes were obtained from patient 1.14 who had a splenectomy due to a lymphoproliferative disorder associated with agammaglobulinemia. Cultures of splenic lymphocytes gave rise to LCL upon EBV infection but not in the absence of added virus. In addition, one patient with $\mathrm{X}$-linked agammaglobulinemia who had B cells in his peripheral blood (patient 4.8) was the source of another LCL.

Three patients with common varied agammaglobulinemia had B lymphocytes that responded to antigen and LMF in short-term culture by synthesizing but not secreting Ig. 16 cultures initiated with EBV from these patients failed to result in the establishment of any LCL.

Fractionation of lymphocytes. Lymphocytes from three patients were fractionated on discontinuous BSA gradients. Three fractions, consisting of cells with the characteristics of B cells (fraction 3 ), $T$ cells (fraction 2), and precursors to $\mathrm{T}$ and $\mathrm{B}$ cells (fraction 1 ) were used to initiate cultures with EBV. Table III shows the results of this experiment. Because patient 8.20 had X-linked agammaglobulinemia without B lymphocytes, there were inadequate numbers of cells from fraction 3 to test. As was found with unfractionated lymphocytes, no cell lines were established from any fraction of his lymphocytes. In contrast, all three fractions from the two patients with B cells (5.6 and 4.23) who were tested resulted in the establishment of LCL. The B-cell lines derived from fraction 2 presumably represent contamination of this $\mathrm{T}$-cell preparation by small numbers of $B$ cells and are an indication of the ability of small numbers of appropriate cells to give

TABLE III

Lymphoid Cell Lines from Fractionated Lymphocytes

\begin{tabular}{|c|c|c|c|c|c|c|}
\hline \multirow[b]{3}{*}{ Patient } & \multicolumn{6}{|c|}{ Fraction } \\
\hline & \multicolumn{2}{|c|}{1} & \multicolumn{2}{|c|}{2} & \multicolumn{2}{|c|}{3} \\
\hline & $\begin{array}{l}\text { Initi- } \\
\text { ated }\end{array}$ & $\begin{array}{l}\text { Estab- } \\
\text { lished }\end{array}$ & $\begin{array}{l}\text { Initi- } \\
\text { ated }\end{array}$ & $\begin{array}{l}\text { Estab- } \\
\text { lished }\end{array}$ & $\begin{array}{l}\text { Initi- } \\
\text { ated }\end{array}$ & $\begin{array}{l}\text { Estab- } \\
\text { lished }\end{array}$ \\
\hline 8.20 & 2 & 0 & 2 & 0 & 0 & 0 \\
\hline 5.6 & 2 & 2 & 2 & 2 & 2 & 2 \\
\hline 4.23 & 4 & 4 & 4 & 4 & 4 & 4 \\
\hline
\end{tabular}

rise to LCL. Unfractionated lymphocytes from these two patients had also given rise to LCL.

In all, LCL were established from six agammaglobulinemic patients. All four patients whose B lymphocytes had been reported to be unresponsive to mitogenic stimulation had cells capable of establishing LCL. No LCL were established from patients who lacked B lymphocytes. Fractionation of peripheral lymphocytes demonstrated that we could establish cell lines when fewer than $1 \%$ B cells were present. The establishment of LCL was not suppressed by the presence of $T$ cells in any of the three fractions. LCL were not established from three patients whose B cells responded to mitogenic stimulation by synthesis of Ig which was not secreted, despite repeated attempts. None of the cultures initiated without added EBV resulted in established LCL.

Lymphocyte surface properties. In view of the failure of B lymphocytes from patients with "nonsecretory" B cells to establish LCL, we examined the surface properties of these patients' cells. Inasmuch as EBV receptors are thought to be a B-cell property associated with C3d receptors, we included C3b and C3d surface receptors in our study.

Normal peripheral blood lymphocytes from two healthy donors and cells from three LCL were examined for EAC3b and EAC3d rosette formation, surface Ig, and EBV receptors (Table IV). Normal lymphocytes expressed all four properties in percentages ranging from 17 to $21 \%$. In samples of peripheral lymphocytes from single individuals, the values obtained for each of the properties examined were within $2 \%$ of the other properties examined. All four characteristics measured the percentage of B lymphocytes in peripheral blood of normal individuals.

The T-cell line, CCRF CEM, did not react with

TABLE IV

B-Cell Markers on Unfractionated Lymphocytes

\begin{tabular}{lcccc}
\hline & \multicolumn{4}{c}{ Peripheral lymphocytes positive for } \\
\cline { 2 - 5 } \multicolumn{1}{c}{ Patient } & $\begin{array}{c}\text { EAC3b } \\
\text { rosettes }\end{array}$ & $\begin{array}{c}\text { EAC3d } \\
\text { rosettes }\end{array}$ & $\begin{array}{c}\text { Surface } \\
\text { Ig }\end{array}$ & $\begin{array}{c}\text { EBV } \\
\text { receptors }\end{array}$ \\
& & \multicolumn{3}{c}{$\%$} \\
Normal lymphocytes & $19-22$ & $17-19$ & $16-19$ & $14-23$ \\
CCRF CEM (T-cell & & & & \\
$\quad$ line) & 0 & 0 & 0 & 0 \\
LAZ 67 (normal B-cell & & & & \\
$\quad$ line) & 48 & 41 & 80 & 76 \\
LAZ 165 (agamma & & & & \\
$\quad$ B-cell line) & 40 & 42 & 64 & 22 \\
20.3 & 20 & 21 & 13 & 0 \\
1.3 & 15 & NT* & 17 & 8 \\
2.3 & 19 & 19 & 16 & 0 \\
\hline
\end{tabular}

* Not tested. 
EAC3b or EAC3d, bear surface Ig, or have EBV receptors, although it did form $\mathrm{E}$ rosettes (data not shown). The two B-cell lines, LAZ 67 and LAZ 165, expressed each of the B-lymphocyte properties. However, the percentage of cells expressing surface Ig, EBV receptors, or EAC3b or EAC3d rosette formation, were not correlated. The percentage of EAC3b (human) and EAC3d (mouse) rosette-forming cells were closely correlated.

Lymphocytes from three patients with nonsecretory $B$ cells which failed to establish LCL were examined for coexpression of the four B-cell properties. Two of the patients had EAC3b and EAC3d rosette-forming cells and surface Ig-bearing cells, but no EBV receptorpositive cells (Table IV). The third patient had a decreased number of EBV receptor-positive cells in relation to the number of surface Ig and EAC3b- and EAC3d-positive cells.

To ensure that the cells that expressed one B cellassociated property were the same cells that expressed other properties, we separated lymphocytes into "precursor," T cell-, and B cell-rich fractions on discontinuous BSA gradients. Normal lymphocytes in each of the three fractions coexpressed the four B cell-associated properties (Table $\mathrm{V}$ ). The precursor-cell fraction contained 21-24\% EAC3b, EAC3d rosette-forming, surface Ig-bearing, and EBV receptor-positive cells; the T-cell fraction 2 contained about $5-7 \%$ such B-cell marked cells; and the B cell-rich fraction 3 contained $62-88 \%$ positive cells.

Peripheral lymphocytes from two patients were fractionated before examination (Table V). Of primary concern is the B cell-rich fraction 3. From two patients,

TABLE V

B-Cell Markers on Fractionated Lymphocytes

\begin{tabular}{|c|c|c|c|c|c|}
\hline \multirow[b]{2}{*}{ Patient } & \multicolumn{5}{|c|}{ Cells reactive with } \\
\hline & E & EAC3b & EAC3d & $\begin{array}{l}\text { Surface } \\
\text { Ig }\end{array}$ & $\begin{array}{l}\text { EBV re- } \\
\text { ceptors }\end{array}$ \\
\hline & \multicolumn{5}{|c|}{$\%$} \\
\hline \multicolumn{6}{|c|}{ Normal lymphocytes } \\
\hline Fraction $1^{*}$ & 24 & 23 & 21 & 24 & 24 \\
\hline 2 & 65 & 5 & 6 & 6 & 7 \\
\hline 3 & 7 & 62 & 62 & 88 & 84 \\
\hline \multicolumn{6}{|l|}{10.13} \\
\hline Fraction 1 & 21 & NT & 42 & 15 & 0 \\
\hline 2 & 54 & 13 & 14 & 5 & 0 \\
\hline 3 & 5 & 46 & 69 & 60 & 0 \\
\hline \multicolumn{6}{|l|}{18.12} \\
\hline Fraction 1 & NT & NT & NT & NT & 0 \\
\hline 2 & 73 & 15 & 14 & NT & 0 \\
\hline 3 & 9 & 54 & 58 & NT & 0 \\
\hline
\end{tabular}

* Fraction 1, precursor-rich fraction; fraction 2, $\mathrm{T}$ cell-rich fraction; fraction 3, B cell-rich fraction.

$\ddagger$ Not tested. most of the cells in this fraction were EAC $3 b$ and EAC3d rosette forming and surface Ig bearing, but none of the cells was EBV receptor positive. The T cellrich and precursor-cell fractions from these two patients were also without EBV receptor-positive cells.

Characterization of LCL. The six LCL derived from five agammaglobulinemic patients were examined for immunological characteristics associated with long-term B-lymphoid cell lines. These properties were $\mathrm{C} 3$ receptors, surface immunoglobulin, cytoplasmic immunoglobulin, and immunoglobulin synthesis and secretion. All LCL were studied during the 1st mo after being established. Because of the possiblity of restriction of immunoglobulin production with increasing time in culture, the cell lines were examined at least once more after 6-12 mo in culture. No drift of immune properties has been noted, even in cell lines that have now been in culture for more than $2 \mathrm{yr}$.

Cells from all six of the cell lines formed EAC3 rosettes in percentages varying between 37 and $66 \%$ (Table VI). These values are comparable to the percent rosette-forming cells from B-LCL derived from normal individuals $(30-70 \%)$. None of the LCL formed rosettes with $\mathrm{E}$, indicating the B-cell character of these EBV-derived LCL.

Two cell lines (LAZ 135 and LAZ 165) showed surface fluorescence with antisera to $\gamma-\alpha-, \mu$-, and $\delta$ heavy chains (Table VI). The remaining four LCL (LAZ 153, S-2, LAZ 184, and LAZ 202) showed fluorescence with antisera to $\delta$ - and $\mu$-heavy chains, but not to $\gamma$ - or $\alpha$-heavy chains. The predominant class of immunoglobulin on the surface of these LCL was IgD, with IgM present only on a lesser percentage of the cells. Preincubation of the cells with normal rabbit serum or heat-aggregated rabbit serum Ig did not alter these results.

The four cell lines that showed predominantly surface IgD were examined for intracellular Ig by fixed cell immunofluorescence. LAZ 202 showed fluores-

TABLE VI

Surface Properties of Lymphoid Cell Lines

\begin{tabular}{|c|c|c|c|c|c|c|c|}
\hline \multirow[b]{2}{*}{ Cell line } & \multirow[b]{2}{*}{ Patient } & \multirow{2}{*}{$\begin{array}{c}\mathbf{E} \\
\text { rosettes }\end{array}$} & \multirow{2}{*}{$\begin{array}{l}\mathrm{EAC}_{3} \\
\text { rosettes }\end{array}$} & \multicolumn{4}{|c|}{$\begin{array}{l}\text { Surface } \mathrm{Ig} \\
\text { antiserum to human }\end{array}$} \\
\hline & & & & $\gamma$ & $\alpha$ & $\mu$ & $\delta$ \\
\hline & & $\%$ & $\%$ & & & & \\
\hline LAZ 135 & 5.8 & 0 & 53 & 42 & 22 & 61 & 30 \\
\hline LAZ 153 & 4.23 & 0 & 43 & 0 & 0 & 3 & 37 \\
\hline S-2 & 4.23 & 0 & 48 & 0 & 0 & 10 & 84 \\
\hline LAZ 165 & 1.14 & 0 & 40 & 36 & 18 & 27 & 19 \\
\hline LAZ 184 & 18.3 & 0 & 37 & 0 & 0 & 11 & 36 \\
\hline LAZ 202 & 10.2 & 0 & 51 & 0 & 0 & 27 & 22 \\
\hline LAZ 67 & $\begin{array}{l}\text { Normal } \\
\text { control }\end{array}$ & 0 & 48 & 35 & 60 & 42 & 32 \\
\hline
\end{tabular}


cence only with antisera to $\delta$-chains (Table VII). The $\mu$-chains present on the surface of some of these cells were apparently not synthesized in sufficient quantity to cause intracellular fluorescence. $88 \%$ of the cells from LAZ 153 were fluorescent with antisera to $\delta$-heavy chains and an additional $23 \%$ reacted with antiserum to $\mu$-chains. The other cell line from this patient, S-2, showed low numbers of cells fluorescent with antisera to $\delta$-, $\mu$-, and a few (6\%) to $\gamma$-chains. Cells from LAZ 184 were similarly reactive with fluorescent antisera to $\delta$ - and $\mu$-heavy chains, and again a few cells $(4 \%)$ to $\gamma$-heavy chains.

Supernatant medium and cytoplasmic lysate preparations from cells incubated with $\left[{ }^{14} \mathrm{C}\right]$ leucine were precipitated with antisera specific for $\mu-, \gamma-, \alpha-$, or $\delta$-heavy chains, K- and $\lambda$-light chains, human Ig (specific for $\gamma-, \alpha-, \mu$-, and $\delta$-heavy chains and $\kappa^{-}$and $\lambda$-light chains), or with normal rabbit serum. Each of these precipitates was redissolved, reduced, and alkylated, and electrophoresed in SDS-acrylamide gels. Fig. 1 shows the autoradiographs of electrophoretic gels containing precipitates obtained with antiserum to human Ig. Two of the LCL (LAZ 135 and LAZ 165) showed de novo Ig synthesis and secretion. IgG and IgM production were identified by mobility in the SDS-gels and by precipitation with antiserum to $\mu$ and $\gamma$-heavy chains. These two cell lines had surface IgG, A, M, and D. The remaining four cell lines ( $\mathrm{LAZ}$ 153, LAZ 184, LAZ 202, and S-2) did not show de novo Ig production. LAZ 153 showed trace bands comigrating with $\gamma$ - and $\mathrm{L}$ chains; however, precipitation of radioactive material from $100 \times 10^{6}$ cells with antiserum to $\gamma$-heavy chains failed to confirm the production of IgG by this cell line. These four cell lines produced a protein that comigrated with $\mu$-heavy chains. This protein was precipitable with antisera to $\gamma-, \alpha-$, and $\delta$-heavy chains and with normal rabbit serum. The nonspecific precipitation and the absence of associated light chains indicate that this material was not immunoglobulin.

The determination of immunoglobulin production or lack of production was confirmed by a radioimmunoassay. By indirect precipitation, the percentage of

TABLE VII

Intracellular Fluorescein Isothiocyanate Staining

\begin{tabular}{lccrr}
\hline & \multicolumn{5}{c}{ Fixed cells staining with antiserum to } \\
\cline { 2 - 5 } Cell line & $\gamma$ & $\alpha$ & $\mu$ & $\delta$ \\
\hline & & & $\%$ & \\
LAZ 15.3 & $0-1$ & 0 & 23 & 88 \\
S-2 & 6 & 0 & 15 & 17 \\
LAZ 184 & 4 & 0 & 6 & 32 \\
LAZ 202 & 0 & 0 & 0 & 8 \\
\hline
\end{tabular}

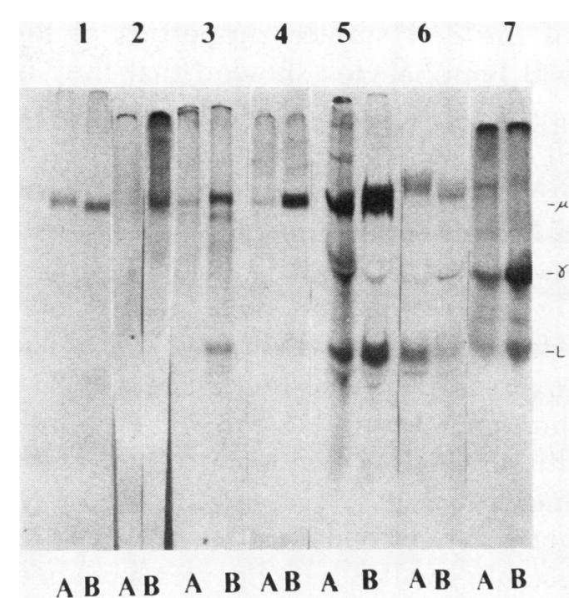

FIGURE 1 Autoradiographs of SDS-gel electrophoresis of immune precipitates (antiserum to human Ig) from LCL. (A) Cytoplasmic proteins. (B) Proteins secreted into the culture medium. (1) LAZ 202, (2) LAZ 184, (3) LAZ 153, (4) S-2, (5) LAZ 165, (6) LAZ 135, (7) LAZ 67 (normal control).

TCA-precipitable protein that could be identified as immunoglobulin was determined. Immunoglobulin production was found in the cell lines LAZ 135 and LAZ 165. In contrast, the remaining four cell lines, LAZ 153, LAZ 184, LAZ 202, and S-2, failed to produce immunoglobulin detectable by this technique (Table VIII).

\section{DISCUSSION}

Patients with agammaglobulinemia who have no detectable small B lymphocytes in their blood lack cells capable of giving rise to EBV-transformed LCL. In contrast, patients with $B$ cells that fail to respond to mitogenic stimulation have EBV-transformable cells, which yield LCL. Furthermore, patients with B lymphocytes that respond to mitogenic stimulation by the synthesis of immunoglobulin which is not secreted fail to give rise to EBV-transformed LCL. Exam-

TABLE VIII

Immunoglobulin Production

\begin{tabular}{lcc}
\hline & \multicolumn{2}{c}{ TCA-precipitable protein } \\
\cline { 2 - 3 } & Secreted & Cytoplasmic \\
\hline & & $\%$ \\
LAZ 67 & 12.5 & 8.6 \\
LAZ 135 & 8.3 & 0 \\
LAZ 165 & 5.1 & 5.6 \\
LAZ 184 & 0 & 0 \\
LAZ 202 & 0 & 0 \\
LAZ 153 & 0 & 0 \\
S-2 & 0 & 0 \\
CCRF CEM & 0 & 0 \\
\hline
\end{tabular}


ination of the cell surface properties of these nonsecretory B lymphocytes showed that they have C3b and $\mathrm{C} 3 \mathrm{~d}$ receptor-bearing and surface immunoglobulinbearing B cells which lack detectable EBV receptors. Characterization of the immunologic properties of established LCL from agammaglobulinemic patients revealed that most LCL had C3 receptors but restricted surface Ig expression and no synthesis of immunoglobulin for export. However, two LCL had C3 receptors, expressed surface IgG, A, M, and D, and produced immunoglobulin that was secreted into the culture medium, which is analogous to LCL derived from normal individuals.

Peripheral blood lymphocytes from patients who lack detectable small B lymphocytes have been shown to contain some EAC3 rosette-forming, surface IgMbearing lymphocytes which sedimented in fraction 1 of BSA gradients (28). Percy et al. (5) have found anti-E plaque-forming cells in PWM-stimulated lymphocytes from patients with X-linked agammaglobulinemia who had no small B lymphocytes. The plaque-forming cell population is presumably contained in the fraction 1 population of precursor cells. These studies suggested that these patients have precursors to small B lymphocytes. Despite this, lymphocytes from these patients failed to establish LCL in response to EBV infection. BSA-gradient fractionation, used in an attempt to concentrate the precursor cells, also failed to yield LCL, indicating that such cells are not susceptible to EBV transformation.

We were unable to establish LCL from patients with nonsecretory B cells. These lymphocytes are unique in their failure on repeated attempts to establish cell lines in response to $\mathrm{EBV}$ infection. This failure led us to reexamine the $B$ cell-associated properties of lymphocytes from all of our patients whose B cells were nonsecretory. Lymphocytes from five patients with this defect were examined. All five patients had normal numbers of B lymphocytes in their peripheral blood when assessed by $\mathrm{C} 3 \mathrm{~b}$ and $\mathrm{C} 3 \mathrm{~d}$ receptors and surface immunoglobulin. Four of the five patients had no EBV receptor-bearing lymphocytes as judged by antiserum to EBV provided by Dr. Jondal. A minimum of 500 cells was scanned, and no positive cells were found. The remaining patient had fewer $B$ cells defined by EBV receptors than B cells defined by C3b and C3d receptors and surface immunoglobulin. Isolated nonsecretory B-lymphocyte fractions also had no EBV receptors. Other BSA fractions had fewer C3b and C3d receptor- and surface immunoglobulin-bearing cells but no EBV receptor-bearing cells.

Our results are in agreement with the studies of Greaves et al. (37) and Jondal and Klein (38) that B lymphocytes contain the population of cells with EBV receptors, and further agree with the study of Hayward and Greaves (39) that patients who lack B lymphocytes by other surface characteristics lack cells susceptible to EBV infection. The failure of nonsecretory B lymphocytes to establish LCL and the absence of detectable EBV receptors is in contradiction of the expected B-cell susceptibility to EBV infection and represents a unique finding. Jondal et al. (40) and Yefenof et al. (41) have previously shown a close correlation between EBV receptors and C3d receptors. The experiments we performed on the nonsecretory $B$ lymphocytes demonstrated that EBV receptors on B cells are distinct from C3d receptors.

Nonsecretory B lymphocytes may represent an unusual stage of differentiation. EBV receptors are lacking from plasma cells. At some stage in the differentiation of small B lymphocytes into antibodysecreting plasma cells, EBV receptors are lost. Nonsecretory B lymphocytes may be unable to differentiate into plasma cells, retaining some characteristics (C3 receptors and surface Ig) of small B lymphocytes but not EBV receptors. Alternatively, the absence of $\mathrm{EBV}$ receptors may be secondary to a glycosylation defect, similar to other reports $(42,43)$.

Common varied agammaglobulinemia is usually associated with the presence of B lymphocytes that fail to produce immunoglobulin. In most studies, this failure to produce immunoglobulin has been associated with a failure to respond to mitogenic stimulation $(6-10,44)$. EBV can serve as a B-cell mitogen, inducing IgM production (13). In the patients we studied, lymphocytes that failed to respond to LMF stimulation responded to EBV stimulation and infection by increased cell division resulting in immortalization. This suggests that EBV stimulates B lymphocytes by a different mechanism than PWM or LMF.

We established LCL from only 5 of the 13 patients we studied. All of the cell lines were established from $B$ cells that failed to respond to mitogenic stimulation. Four cell lines derived from three patients had cells with immunologic characteristics of primitive, or precursor, B lymphocytes. The properties were the presence of C3 receptors, surface and intracellular IgD, and no detectable immunoglobulin production. Two cell lines derived from two patients had immunologic characteristics of B-cell lines derived from normal individuals. These properties were the presence of C3 receptors, surface immunoglobulin of several classes, and synthesis and secretion of radioactively labeled immunoglobulin.

Four cell lines showed a primary pattern of surface or intracellular fluorescence with antiserum to IgD. These cell lines did not have significant numbers of surface IgG-, IgA-, or IgM-bearing cells and they did not synthesize immunoglobulin for export. The cell line S-2 had surface IgD on $84 \%$ of the cells, with $10 \%$ expressing surface IgM. Many fewer cells had intracellular fluorescence with antiserum to $\operatorname{IgD}(17 \%)$ 
and IgM (15\%). The cell line LAZ 153 had more cells with intracellular IgD (88\%) and IgM (23\%) than cells with surface IgD $(37 \%)$ or IgM $(3 \%)$. These two cell lines were derived from the same patient at different times. The consistent expression of IgD, either as cell surface or as intracellular molecules, demonstrates an intrinsic maturational defect in the B cells from this patient. The other two cell lines (LAZ 184 and LAZ 202) also predominantly expressed surface and intracellular IgD, with a smaller component of IgM-bearing cells. None of these cell lines secreted immunoglobulin. The phenotype of these cell lines may represent a developmental block due to intrinsic $\operatorname{defect}(\mathrm{s})$ in these patients' B lymphocytes.

A small number of cells from LAZ 184 and S-2 had intracellular IgG. No surface IgG-bearing cells were found in these cultures. These few cells may represent a transition state between the IgD-bearing primitive $B$ cells and a more differentiated state which synthesizes IgG. Radioactively labeled culture medium from LAZ 153 showed a small amount of material which comigrated with $\gamma$ - and L chains in electrophoresis. There may be a small number of cells in these cultures which synthesize IgG that was not detected by immunofluorescence.

Cell lines derived from two patients, LAZ 135 and LAZ 165, had immune characteristics that were indistinguishable from LCL derived from normal individuals. These findings are in contrast to previous studies which showed that isolated B lymphocytes from patient 4.5 (LAZ 135) failed to respond to mitogenic stimulation (8). Two explanations of this discrepancy suggest themselves. First, this patient may have normal, responsive B lymphocytes present in insufficient numbers to have been detected in previous studies. Alternatively, these B lymphocytes may be defective in mitogenic or antigenic triggering. EBV transformation may be able to circumvent such an intrinsic defect. If the latter explanation is correct, LAZ 135 and LAZ 165 may be defective in immunologic properties which were not tested in these studies.

Prolonged cultivation of a LCL may result in phenotypic restriction to production of a single class of immunoglobulin $(16,17,45)$. All of the agammaglobulinemic cell lines were examined during the 1st mo after they were established and at least once again after 6-12 mo of culture. We saw no alterations in the phenotype of the cell lines. In particular, the IgDbearing cell lines that did not produce immunoglobulin had this phenotype from the time of being established. This phenotype was stable.

The IgD-bearing LCL we studied were derived from surface IgD- and IgM-bearing B lymphocytes from patients with agammaglobulinemia.

The discordance of expression of surface and intracellular immunoglobulin in these cell lines reiterates previous studies which showed the independent expression of these two properties $(46,47)$. The establishment of LCL that do not secrete immunoglobulin serves to dissociate the property of "immortalization" associated with EBV infection from the property of differentiation. The surface IgD-bearing LCL derived from patients with agammaglobulinemia present new opportunities for the study of B-lymphocyte development and differentiation. Unlike B lymphocytes from the patients' peripheral blood, they are available in unlimited quantities. Finally, detailed analysis of the properties of these cell lines may show alterations from the normal state which will confirm or deny hypothesized functions of B-lymphocyte properties.

\section{ACKNOWLEDGMENTS}

We thank E. Barell and K. Pearson for expert technical assistance, and Doctors George Baker and Douglas Fearon for allowing study of their patients.

This work was supported by grants AI-05877, RR-128, and contract NO1-CP-53539 of the U. S. Public Health Service and the Joanne Paley Memorial Fund.

\section{REFERENCES}

1. Cooper, M. D., and A. R. Lawton. 1972. Circulating B cells in patients with immunodeficiency. Am. J. Pathol. 69: $513-528$

2. Siegal, F. P., B. Pernis, and H. G. Kunkel. 1971. Lymphocytes in human immunodeficiency states: A study of membrane-associated immunoglobulins. Eur. J. Immunol. 1: $482-486$.

3. Geha, R. S., F. S. Rosen, and E. Merler. 1973. Identification and characterization of subpopulations of lymphocytes in human peripheral blood after fractionation on discontinuous gradients of albumin. J. Clin. Invest. 52: $1726-1734$.

4. Gatien, J. G., E. E. Schneeberger, R. Parkman, and E. Merler. 1975. Isolation on discontinuous gradients of bovine albumin of a subpopulation of human lymphocytes exhibiting precursor characteristics. Eur. J. Immunol. 5: 306-312.

5. Percy, M. E., H. M. Dosch, and E. W. Gelfand. 1977. In vitro biosynthesis of specific IgM antibody by lymphocytes from patients with congenital agammaglobulinemia. Fed. Proc. 36: 1268A. (Abstr.)

6. Choi, Y. S., W. D. Biggar, and R. A. Good. 1972. Biosynthesis and secretion of immunoglobulins by peripheral blood lymphocytes and in severe hypogammaglobulinemia. Lancet. I: 1149-1151.

7. de la Concha, E. G., G. Oldham, A. D. B. Webster, G. L. Asherson, and T. A. E. Platts-Mills. 1977. Quantitative measurement of $\mathrm{T}$ and B cell function in "variable" primary hypogammaglobulinemia: Evidence for a consistent B-cell defect. Clin. Exp. Immunol. 27: 208-215.

8. Geha, R. S., E. E. Schneeberger, F. S. Rosen, and E. Merler. 1974. Heterogeneity of "acquired" or common variable agammaglobulinemia. N. Engl. J. Med. 291: 1-6.

9. Siegal, F. P., M. Siegal, and R. A. Good. 1976. Suppression of B-cell differentiation by leukocytes from hypogammaglobulinemic patients. J. Clin. Invest. 58: 109-122.

10. Broom, B. C., E. G. de la Concha, A. D. B. Webster, G. J. Janossy, and G. L. Asherson. 1976. Intracellular immunoglobulin production in vitro by lymphocytes from patients 
with hypogammaglobulinemia and their effect on normal lymphocytes. Clin. Exp. Immunol. 23: 73-82.

11. Greaves, M., and G. Janossy. 1972. Elicitation of selective $\mathrm{T}$ and $\mathrm{B}$ lymphocyte responses by cell surface binding ligands. Transplant. Rev. 11: 87-130.

12. Geha, R., E. Schneeberger, E. Merler, and F. S. Rosen. 1973. Interaction of human thymus-derived and nonthymus-derived lymphocytes in vitro. J. Exp. Med. 138: 1230-1247.

13. Rosen, A., P. Gergely, M. Jondal, G. Klein, and S. Britton. 1977. Polyclonal Ig production after Epstein-Barr virus infection of human lymphocytes in vitro. Nature (Lond.). 267: 52-54.

14. Winchester, R., S. Fu, T. Hoffman, and H. Kunkel. 1975. IgG on lymphocyte surfaces: Technical problems and the significance of a third cell population. J. Immunol. 114: 1210-1212.

15. Cooper, M. D., J. Kearney, A. Lawton, E. Abney, R. Parkhouse, J. Preud'homme, and M. Seligmann. 1976. Generation of immunoglobulin class diversity in B cells: A discussion with emphasis on IgD development. Ann. Immunol. (Paris). 127C: 573-581.

16. Nilsson, K. 1971. High frequency establishment of human immunoglobulin-producing lymphoblastoid lines from normal and malignant lymphoid tissue and peripheral blood. Int. J. Cancer. 8: 432-442.

17. Glade, P. R., and P. S. Papageorgiou. 1974. Human lymphoid cell lines: Models for immunological analysis. In Vitro. 9: 202-215.

18. van Boxel, J., and D. Buell. 1974. IgD on cell membranes of human lymphoid cell lines with multiple immunoglobulin classes. Nature (Lond.). 251: 443-444.

19. Bøyum, A. 1976. Isolation of lymphocytes, granulocytes, and macrophages. Scand. J. Immunol. 5 (Suppl. 5): 9-15.

20. Iwakata, S., and J. T. Grace. 1964. Cultivation in vitro of myeloblasts from human leukemia. N. Y. State J. Med. 64: 2279-2281.

21. Eagle, H. 1959. Amino acid metabolism in mammalian cell cultures. Science (Wash. D. C.). 130: 432.

22. Lazarus, H., E. Barell, and S. Oppenhein. 1974. Stimulation of lymphoid cells by sulfur containing compounds. In Vitro. 9: 370A (Abstr.)

23. Miller, G., and M. Lipman. 1973. Release of infectious Epstein-Barr virus by transformed marmoset leukocytes. Proc. Natl. Acad. Sci. U. S. A. 70: 190-194.

24. Robinson, J., and G. Miller. 1975. Assay for Epstein-Barr virus based on stimulation of DNA synthesis in mixed leukocytes from human umbilical cord blood. J. Virol. 15: $1065-1072$.

25. Moore, G., A. Sandberg, and K. Ulrich. 1966. Suspension cell culture and in vivo and in vitro chromosome constitution of mouse leukemia L1210. J. Natl. Cancer Inst. 36: 405-413.

26. Foley, G., H. Lazarus, S. Farber, B. Uzman, B. Boone, and M. MacCarty. 1965. Continuous culture of human lymphoblasts from peripheral blood of a child with acute leukemia. Cancer. 18: 522-529.

27. Kaplan, J., T. Shope, and W. Peterson. 1974. EpsteinBarr virus-negative human malignant T-cell lines. J. Exp. Med. 139: 1070-1076.

28. Dicke, K., G. Tridente, and D. van Bekkum. 1969. The selective elimination of immunologically competent cells from bone marrow and lymphocyte cell mixtures. Transplantation (Baltimore). 8: 422-434.

29. Eden, A., G. Miller, and V. Nussenzweig. 1973. Human lymphocytes bear membrane receptors for C3b and C3d. J. Clin. Invest. 52: 3239-3242.

30. Ross, G., M. Polley, E. Rabellino, and H. Grey. 1973. Two different complement receptors on human lymphocytes. J. Exp. Med. 138: 798-811.
31. Ross, G. D., and M. J. Polley. 1976. Assay for the two different types of lymphocyte complement receptors. Scand. J. Immunol. 5 (Suppl. 5): 99-112.

32. Fuchs, S., and M. Sela. 1973. Immunoadsorbents. In Handbook of Experimental Immunology. Vol. 1. D. M. Weir, editor. Blackwell Scientific Publications Ltd., Oxford.

33. Goldman, M. 1968. Fluorescent Antibody Methods. Academic Press, Inc., New York. 97-104.

34. Johnson, G. D., and E. J. Holboson. 1973. Immunofluorescence. In Handbook of Experimental Immunology. Vol. 1. D. M. Weir, editor. Blackwell Scientific Publications, Ltd., Oxford.

35. Jondal, M. 1976. Assays for Epstein-Barr virus (EBV) receptors. In Methods in Cell Mediated Immunity. B. Bloom and J. David, editors. 2nd edition. Academic Press, Inc., New York. 187-191.

36. Maizel, J. V. 1971. Polyacrylamide gel electrophoresis of viral proteins. In Methods of Virology. Vol. 5. K. Maramorosch and H. Koprowski, editors. Academic Press, Inc., New York. 179-246.

37. Greaves, M. F., G. Brown, and A. B. Rickinson. 1975. Epstein-Barr virus binding sites on lymphocyte subpopulations and the origin of lymphoblasts in cultured lymphoid cell lines and in the blood of patients with infectious mononucleosis. Clin. Immunol. Immunopathol. 3: 514-524.

38. Jondal, M., and G. Klein. 1973. Surface markers on human B and T lymphocytes. II. Presence of Epstein-Barr virus receptors on B lymphocytes. J. Exp. Med. 138: 1365-1378.

39. Hayward, A. R., and M. F. Greaves. 1975. Central failure of B lymphocyte induction in pan-hypogammaglobulinemia. Clin. Immunol. Immunopathol. 3: 461-470.

40. Jondal, M., M. B. A. Oldstone, V. Bokish, and E. Yefenof. 1976. Surface markers on human $B$ and $T$ lymphocytes. VIII. Association between complement and EpsteinBarr virus receptors on human lymphoid cells. Scand. J. Immunol. 5: 401-410.

41. Yefenof, E., G. Klein, M. Jondal, and M. Oldstone. 1976. Surface markers on human B and T lymphocytes. IX. Two color immunofluorescence studies on the association between EBV receptors and complement receptors on the surface of lymphoid cell lines. Int. J. Cancer. 17: 693-700.

42. Ciccimara, F., F. S. Rosen, E. E. Schneeberger, and E. Merler. 1976. Failure of heavy chain glycosylation of IgG in some patients with common variable agammaglobulinemia. J. Clin. Invest. 57: 1386-1390.

43. Weitzman, S., and M. D. Scharff. 1977. Abnormalities in the glycosylation of immunoglobulin heavy chain and an $\mathrm{H}-2$ transplantation antigen in a mouse myeloma mutant. Cell. 10: 679-687.

44. de la Concha, E. G., G. Oldham, A. D. B. Webster, G. L. Asherson, and T. A. E. Platts-Mills. 1977. Quantitative measurements of $\mathrm{T}$ - and B-cell function in "variable" primary hypogammaglobulinemia: Evidence for a consistent B-cell defect. Clin. Exp. Immunol. 27: 208-215.

45. Evans, J., M. Steel, and E. Arthur. 1974. A hemagglutination inhibition technique for detection of immunoglobulins in supernatants of human lymphoblastoid cell lines. Cell. 3: 153-158.

46. Litwin, S. D., T. Hutteroth, P. Lin, J. Kennard, and H. Cleve. 1974. Immunoglobulin expression of cells from human lymphoblastoid lines. II. Interrelationship among surface, cellular, and secreted immunoglobulins. J. Immunol. 113: 668-672.

47. Premkumar, E., P. Singer, and A. R. Williamson. 1975. A human lymphoid cell line secreting immunoglobulin $G$ and retaining immunoglobulin $M$ in the plasma membrane. Cell. 5: 87-92. 